\title{
Effect of Planting Techniques with Organic and Inorganic Nutrient Management on Growth, Yield Attributes and Productivity of Rice (Oryza sativa L.) under Rice-Wheat Cropping System
}

\author{
G. Naveen Kumar ${ }^{\text {** }}$, P. K. Singh ${ }^{1}$, R. K. Naresh ${ }^{1}$, \\ M. Sharath Chandra ${ }^{1}$ and Akash Kumar ${ }^{2}$ \\ ${ }^{1}$ Department of Agronomy, Sardar Vallabhbhai Patel University of Agriculture \& Technology, \\ Meerut, Uttar Pradesh, India \\ ${ }^{2}$ Department of Floriculture \& Landscape Architecture, Dr. YSP University of Horticulture \\ and Forestry, Solan, H.P., India \\ *Corresponding author:
}

\section{A B S T R A C T}

\section{Keywords}

Planting techniques, Fertility levels, Growth parameters, Yield attributes, Yield

\section{Article Info}

Accepted:

04 December 2020

Available Online:

10 January 2021
A field experiment was conducted at Sardar Vallabhbhai Patel University of Agriculture \& Technology, Meerut (U.P.), during the Kharif season 2019 to study the effect of planting techniques with organic and inorganic nutrient management on growth, yield attributes and yield of rice (Oryza sativa L.) under rice-wheat cropping system. The treatment comprised of four planting techniques as main treatments and six fertility levels as subplot treatments in split plot design with three replications. The results indicated that conventional tillagetransplanted rice (CT-TPR) $\left(\mathrm{M}_{2}\right)$ recorded significantly highest growth characters (except plant height), yield attributes and yield over furrow irrigated raised beds (FIRB) $\left(\mathrm{M}_{3}\right)$ and reduced tillage-transplanted rice (RT-TPR) $\left(\mathrm{M}_{1}\right)$, which remained at par with unpuddledtransplanted rice (UP-TPR) $\left(\mathrm{M}_{4}\right)$ respectively. The plant height was maximum in furrow irrigated raised beds (FIRB). Among fertility levels treatments, the application of $100 \%$ $\mathrm{NPK}+25 \% \mathrm{~N}(\mathrm{FYM})\left(\mathrm{S}_{6}\right)$ found higher growth, yield attributes, and yield than rest of the other fertility treatments. Thus, the results suggest that inclusion of inorganic fertilizer along with organic manure (FYM) enhanced the rice yield. Therefore, application of $\mathrm{M}_{2}$ (CT-TPR) along with $\mathrm{S}_{5}(75 \% \mathrm{NPK}+25 \% \mathrm{~N}(\mathrm{FYM})$ ) found beneficial to increase growth and productivity of rice crop.

\section{Introduction}

Rice is one of the world's largest cereal food crop and dietary staple providing the caloric need for millions of people. India stands the second largest producer and consumer of rice in the world after china. In India, the area, production and productivity of rice is $43.77 \mathrm{M}$ ha, $112.76 \mathrm{mt}$ and $2.57 \mathrm{t} / \mathrm{ha}$, respectively. However, Uttar Pradesh is the one of the major rice crop growing state. Rice occupies an area of $5.86 \mathrm{M}$ ha, produces $15.54 \mathrm{mt}$ rice with a productivity of $2.46 \mathrm{t} / \mathrm{ha}$ in UP, (Directorate of Economics and Statistics, 
2018-19). The productivity and sustainability of rice-based cropping systems are threatened because of the inefficient use of inputs, repeated puddling of course and medium textured soils in the state has led to the subsurface compaction in the soils, which has been proving detrimental for the upland crops like wheat. The high bulk density layer at 15 $20 \mathrm{~cm}$ depth formed due to repeated puddling restricts the root growth of wheat. Thus, puddled transplanted system of rice is water, capital and energy intensive, which leads to the structural deterioration of the soil (Bhatt $e t$ al., 2018). In order to take care of the abovesaid issues, various resource conservation technologies (RCTS) viz., conventional tillage $(\mathrm{CT})$, reduced tillage (RT), furrow irrigated raised bed (FIRB), unpuddled transplanting (UT), in rice-wheat. Conventional tillage not only improves soil tilth and root penetration but also reduces soil compaction, nutrient stratification, soil structure and soil organic matter. Jacobs et al., (2010) found that reduced tillage (RT) improves aggregate stability and increased the concentrations of $\mathrm{SOC}$ and $\mathrm{N}$ within the aggregates in the upper $5-8 \mathrm{~cm}$ soil depth. Raised beds are formed by moving soil from the furrows to the area of the bed, thus raising its surface level. The furrows serve as irrigation channels, drains and traffic lanes. Generally, two to six rows are planted on the top of each bed for rice crop. Furrow irrigated raised bed (FIRB) planting system in which crops are sown on ridges or beds. Potential agronomic advantages of beds include improved soil structure due to reduced compaction through controlled trafficking, reduced water logging and timely machinery operations due to better surface drainage. Beds also create the opportunity for mechanical weed control and improved fertilizer placement (Naresh et al., 2012). Even though the area under rice cultivation is large; the productivity is low due to various interaction factors. The imbalance usage of fertilizers is one of the main factors responsible for the low productivity and also the continuous use of inorganic fertilizers resulted in declining of soil fertility. The use of organic manures alone might not meet the plant requirement due to presence of relatively low content of nutrients. Application of organic manure with chemical fertilizer accelerates the microbial activity, increases nutrient use efficiency enhances the availability of the native nutrients to the plants resulting higher nutrient uptake. Therefore, in order to make the soil well supplied with all the plant nutrients in the readily available form and to maintain good soil health, it is necessary to use organic manures in combination with inorganic fertilizers to obtain optimum yields (Mahmud et al., 2016). This implies that the need of integrated nutrient management for rice production. Therefore, the combined use of organic manures and inorganic fertilizers help in maintaining yield stability through correction of marginal deficiencies of secondary and micronutrients, enhancing efficiency of applied nutrients and providing favorable soil physical conditions (Gill and Walia, 2014).

Keeping all these point in mind a field experiment was conducted with different planting techniques including application of organic and inorganic nutrient management as sole and in combination to find out its effect on growth, yield attributes and yield of rice (Oryza sativa L.) under rice-wheat cropping system.

\section{Materials and Methods}

The field experiment was conducted at Sardar Vallabhbhai Patel University of Agriculture \& Technology, Meerut (U.P.), during Kharif season 2019. It was laid out in split plot design with three replications. The treatments comprised of four planting techniques viz. ( $\mathrm{M}_{1}$-Reduced Tillage-Transplanted Rice (RT- 
TPR), $\mathrm{M}_{2}$-Conventional Tillage-Transplanted Rice (CT-TPR), M 3 -Furrow Irrigated Raised Beds (FIRB), $\mathrm{M}_{4}$-Unpuddled-Transplanted Rice (UP-TPR)) as main plot treatments and six fertility levels viz $\left(\mathrm{S}_{1}\right.$-Control, $\mathrm{S}_{2}-100 \%$ NPK Chemical fertilizer, $\mathrm{S}_{3}-100 \%$ N (FYM), $\mathrm{S}_{4}-50 \% \mathrm{NPK}+50 \% \mathrm{~N}(\mathrm{FYM}), \mathrm{S}_{5}-75 \% \mathrm{NPK}$ $+25 \% \mathrm{~N}$ (FYM), $\mathrm{S}_{6}-100 \% \mathrm{NPK}+25 \%$ $\mathrm{N}(\mathrm{FYM})$ ) as subplot treatments and rice variety PB-1 was tested. The soil of experimental site was low in organic carbon $(0.42 \%)$, nitrogen $\left(195.3 \mathrm{~kg} \mathrm{ha}^{-1}\right)$ and medium in available phosphorus $(12.4 \mathrm{~kg}$ ha $\left.{ }^{1}\right)$ and available potassium (118.2 $\left.\mathrm{kg} \mathrm{ha}^{-1}\right)$ and alkaline in reaction.

The data collected from the experiment were analyzed statistically by analysis of variance (ANOVA) method for split plot design with planting techniques and fertility levels as main and sub factor, respectively. Whenever the treatment differences were found significant ( $F$ test), critical differences were worked out at five per cent probability level. Treatment differences that were nonsignificant were denoted by NS. The growth parameters, yield attributes and yield data recorded, analysed and tabulated after statistical test.

\section{Data recorded on growth parameter, yield attributes and yield}

Plant height (cm): Five plants were selected randomly at 30, 60, 90 DAT \& harvest in each treatment and height was measured from ground surface using meter scale.

Number of tillers $/ \mathrm{m}^{2}$ : Number of tillers was recorded from net plot area with the help of quadrate of $1 \mathrm{~m}^{2}$ at $30,60,90 \mathrm{DAT}$ and at harvest stage.

Dry matter accumulation $\left(\mathrm{g}^{-2}\right)$ : Dry matter accumulation was recorded by selecting five hills randomly from observation row of each plot. Selected hills from sampling area were cut carefully closed to the ground surface at 30,60, $90 \mathrm{DAT}$ and at harvest stage. After sun drying these samples were collected in paper bags by cutting in small pieces and put in an electric oven at $65 \pm 10 \mathrm{C}$ till constant weight. After this the weight was recorded on electronic balance and expressed as dry matter accumulation in $\mathrm{g} / \mathrm{m}^{2}$.

Number of effective tillers $/ \mathrm{m}^{2}$ : Shoots bearing panicles at the time of harvesting were recorded by using a quadrate of one square meter in each plot as per procedure followed for counting number of tillers at each successive stage, considered as number of panicles $/ \mathrm{m}^{2}$.

Number of grains per panicles: Ten panicles were selected randomly from each plot and number of grains per ten panicles was counted and average number of grains per panicles was worked out.

1000-grain Weight (g): To avoid biasness, handful seeds were taken from each net plot and thousand seeds were counted randomly and weighed. The average of three sub samples from each plot was taken to compute the final 1000-grain weight.

Grain yield (q $\left.\mathbf{h a}^{\mathbf{- 1}}\right)$ : Grain yield was determined from the net plot area and was weighed in $\mathrm{kg}$ and converted into $\mathrm{q} \mathrm{ha} \mathrm{ha}^{-1}$. Grains were harvested, dried and weighed, and grain weight was taken at $14 \%$ moisture content.

Biological yield ( $\left.\mathbf{q} \mathbf{h a}^{-1}\right)$ : The crop in each net plot will be harvested bundled, labelled and dried in the field for 4-5 days. Bundles will be weighed just before threshing to record biological yield (Grain yield $\mathrm{q} \mathrm{ha}^{-1}+$ straw yield $\mathrm{q} \mathrm{ha}^{-1}$ ) per plot and expressed in $\mathrm{q}$ $\mathrm{ha}^{-1}$. 
Harvest index (\%): The recovery of seed in total biological yield was considered as harvest index which was calculated with the help of following formula.

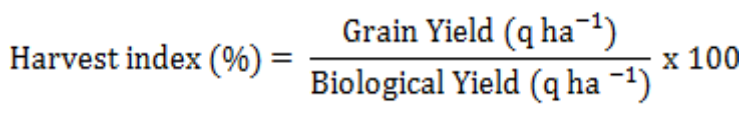

\section{Results and Discussion}

\section{Growth parameters of rice}

\section{Plant height $(\mathrm{cm})$}

The plant height indicated that there was significant effect of different treatments on height of rice crop (Table 1 and Fig. 1). The highest plant height was recorded with $\mathrm{M}_{3}$ (FIRB-TPR) treatment which remained at par with $\mathrm{M}_{2}$ (CT- TPR) at harvest stage. Wider spacing particularly under in FIRB method recorded significantly taller plant than the closer spacing. The fertility levels also caused significant variation in plant height at harvest stage. The maximum plant height was recorded with the application of $\mathrm{S}_{6}(100 \%$ $\mathrm{NPK}+25 \%(\mathrm{FYM})$ ) which was significantly higher than rest of the treatments and lowest plant height was noticed under control treatment. Plant height increased primarily due to adequate nutrient supply to the plant which led to rapid growth by good establishment of root and various metabolic processes and finally performed better mobilization of synthesized carbohydrates in to amino acid and protein which stimulated the rapid cell division and cell elongation. Similar findings were recorded by Tomar et al., (2018).

\section{Number of tillers $/ \mathrm{m}^{2}$}

The number of tillers $/ \mathrm{m}^{2}$ of rice was influenced by different planting techniques and fertility levels (Table 1). Significantly average maximum number of tillers was recorded in $\mathrm{M}_{2}$ (CT- TPR) at harvest stage. Significantly higher number of tillers were recorded with the application of $\mathrm{S}_{6}(100 \%$ $\mathrm{NPK}+25 \% \mathrm{~N}(\mathrm{FYM})$ ) and the minimum number of tillers was recorded in under $S_{1}$ (control) treatment. The higher number of tillers $/ \mathrm{m}^{2}$ might be due to better water management \& better establishment. Alternate wetting and drying maintaining a thin film of water that might open the soil for both oxygen and nitrogen and promoted the root growth during initial growth stages which ultimately increased tiller density.

\section{Dry matter accumulation $\left(\mathrm{g} / \mathrm{m}^{2}\right)$}

Planting techniques and fertility levels caused significant variation in dry matter accumulation at different crop growth stages (Table 1). Highest dry matter accumulated under $\mathrm{M}_{2}$ (CT-TPR) and significantly lowest was observed under the treatment $\mathrm{M}_{1}$ (RTTPR) at harvest. The maximum dry matter accumulation was noticed with the application of $\mathrm{S}_{6}(100 \% \mathrm{NPK}+25 \% \mathrm{~N}(\mathrm{FYM}))$ and significantly lower dry matter accumulation ware recorded under control treatment. This might be due to higher doses of nutrients resulted in higher availability of nutrients in the soil for plant nourishment and further, organic source release slow and continuous availability of nutrients enhanced cell division, elongation as well as various metabolic processes which increased plant growth attributes which ultimately attained the higher tillers \& dry matter accumulation. The results have got close conformity with the findings of Sing et al., (2018).

\section{Yield attributes of rice}

\section{Number of effective tillers $/ \mathrm{m}^{2}$}

Planting techniques \& fertilizers \& FYM levels caused significant variation in number of effective tillers $/ \mathrm{m}^{2}$ in rice (Table 2). 
Highest number of effective tillers (118) were recorded under the treatment $\mathrm{M}_{2}$ (CT-TPR) and lowest number of effective tillers (111) were observed under the treatment $\mathrm{M}_{3}$ (FIRBTPR). Fertility levels also caused significant variation in number of effective tillers $/ \mathrm{m}^{2}$. The highest number of effective tillers was recorded with the application of $\mathrm{S}_{6}[100 \%$ $\mathrm{NPK}+25 \% \mathrm{~N}$ (FYM)]. The significantly lowest number of effective tillers was observed under control treatment.

\section{Grains/Panicle}

Planting techniques, fertility levels caused significant variation in number of grains/panicle in rice (Table 2). The significantly highest number of grains/panicle (130) was recorded under the treatment M2 (CT- TPR) and the lowest number of grains (118) was noticed under the treatment M1
(RT-TPR). The significantly highest grains/panicle (132) were recorded with the application of S6 (100\% NPK + 25\% $\mathrm{N}(\mathrm{FYM})$ ). Lowest value of grains per panicle was observed under control treatment.

\section{Test Weight (g)}

Planting techniques \& fertility levels did not cause any significant variation in test weight (1000 grain weight) of rice (Table 2). The maximum test weight was recorded under $\mathrm{M}_{2}$ (CT-TPR) and minimum test weight was noticed in $\mathrm{M}_{1}$ (RT-TPR).

The test weight was significantly influenced by fertility levels. The maximum test weight was recorded with application of $\mathrm{S}_{6}[100 \%$ $\mathrm{NPK}+25 \% \mathrm{~N}$ (FYM)]. However, the minimum test weight was observed in control treatment (Fig. 2).

Table.1 Effect of planting techniques and fertility levels on growth parameters of basmati rice

\begin{tabular}{|c|c|c|c|}
\hline Treatment & $\begin{array}{c}\text { Plant height } \\
(\mathbf{c m})\end{array}$ & $\begin{array}{l}\text { Number of } \\
\text { tillers } / \mathbf{m}^{2}\end{array}$ & $\begin{array}{c}\text { Dry matter } \\
\text { accumulation } \mathrm{g} / \mathrm{m}^{2}\end{array}$ \\
\hline \multicolumn{4}{|l|}{ Planting techniques } \\
\hline $\mathrm{M}_{1}$ RT- TPR & 101.20 & 298.78 & 855.89 \\
\hline $\mathrm{M}_{2} \mathrm{CT}$ - TPR & 108.18 & 335.15 & 914.42 \\
\hline M $_{3}$ FIRB - TPR & 115.64 & 311.57 & 869.80 \\
\hline$M_{4}$ Unpuddled -TPR & 105.17 & 324.12 & 887.75 \\
\hline$S E m \pm$ & 0.66 & 2.46 & 2.18 \\
\hline$C D(P=0.05)$ & 2.3 & 8.70 & 7.71 \\
\hline \multicolumn{4}{|c|}{ Fertility levels } \\
\hline $\mathbf{S}_{1}$ Control & 94.70 & 263.77 & 802.15 \\
\hline$S_{2} 100 \%$ NPK Chemical fertilizer & 109.62 & 337.71 & 896.98 \\
\hline$S_{3} 100 \%$ N (FYM) & 107.30 & 294.77 & 874.40 \\
\hline $\mathrm{S}_{4} 50 \% \mathrm{NPK}+\mathbf{5 0 \%} \mathrm{N}(\mathrm{FYM})$ & 108.36 & 300.90 & 893.37 \\
\hline$S_{5} 75 \%$ NPK + 25\% N(FYM) & 111.01 & 349.87 & 906.11 \\
\hline $\mathrm{S}_{6} 100 \% \mathrm{NPK}+25 \% \mathrm{~N}(\mathrm{FYM})$ & 114.28 & 357.41 & 918.77 \\
\hline SEm \pm & 0.81 & 2.43 & 5.06 \\
\hline$C D(P=0.05)$ & 2.34 & 6.98 & 14.54 \\
\hline
\end{tabular}


Table.2 Effect of planting techniques and fertility levels on yield contributing characteristics of basmati rice

\begin{tabular}{|c|c|c|c|}
\hline Treatment & $\begin{array}{l}\text { Effective } \\
\text { tillers } / \mathrm{m}^{2}\end{array}$ & Grains/panicle & $\begin{array}{l}\text { Test weight } \\
\text { (g) }\end{array}$ \\
\hline \multicolumn{4}{|l|}{ Planting techniques } \\
\hline$M_{1}$ RT- TPR & 112.71 & 118.44 & 23.35 \\
\hline$M_{2}$ CT- TPR & 118.69 & 130.94 & 23.50 \\
\hline$M_{3}$ FIRB - TPR & 111.92 & 123.11 & 23.46 \\
\hline $\mathrm{M}_{4}$ Unpuddled -TPR & 115.40 & 126.88 & 23.45 \\
\hline SEm \pm & 0.61 & 1.16 & 0.11 \\
\hline$C D(P=0.05)$ & 2.17 & 4.09 & $N S$ \\
\hline \multicolumn{4}{|c|}{ Fertility levels } \\
\hline $\mathbf{S}_{1}$ Control & 42.01 & 115.25 & 22.95 \\
\hline$S_{2} 100 \%$ NPK Chemical fertilizer & 131.54 & 128.83 & 23.45 \\
\hline$S_{3} \mathbf{1 0 0 \%} \mathbf{N}(\mathrm{FYM})$ & 114.54 & 119.91 & 23.02 \\
\hline $\mathrm{S}_{4} \mathbf{5 0 \%} \mathrm{NPK}+\mathbf{5 0 \%} \mathrm{N}(\mathrm{FYM})$ & 127.54 & 123.84 & 23.17 \\
\hline$S_{5} 75 \%$ NPK + 25\% N(FYM) & 136.91 & 128.66 & 23.77 \\
\hline$S_{6} 100 \%$ NPK + 25\% N(FYM) & 135.11 & 132.58 & 24.27 \\
\hline SEm \pm & 0.86 & 0.16 & 0.23 \\
\hline$C D(P=0.05)$ & 2.49 & 0.45 & 0.58 \\
\hline
\end{tabular}

Table.3 Effect of planting techniques and fertility levels on yield of basmati rice

\begin{tabular}{|c|c|c|c|c|}
\hline \multirow[t]{2}{*}{ Treatment } & \multicolumn{3}{|c|}{ Yield q/ha } & \multirow{2}{*}{$\begin{array}{l}\text { Harvest } \\
\text { index } \%\end{array}$} \\
\hline & $\begin{array}{l}\text { Grain } \\
\text { yield }\end{array}$ & $\begin{array}{l}\text { Straw } \\
\text { yield }\end{array}$ & $\begin{array}{c}\text { Biological } \\
\text { yield }\end{array}$ & \\
\hline \multicolumn{5}{|l|}{ Planting techniques } \\
\hline$M_{1}$ RT- TPR & 32.60 & 43.95 & 76.55 & 42.83 \\
\hline $\mathrm{M}_{2} \mathrm{CT}$ - TPR & 38.37 & 53.91 & 92.28 & 40.89 \\
\hline$M_{3}$ FIRB - TPR & 34.09 & 45.71 & 79.81 & 42.08 \\
\hline$M_{4}$ Unpuddled -TPR & 36.21 & 48.04 & 84.25 & 42.30 \\
\hline SEm \pm & 0.17 & 0.28 & 0.73 & 0.28 \\
\hline$C D(P=0.05)$ & 0.62 & 1.01 & 2.58 & $N S$ \\
\hline \multicolumn{5}{|c|}{ Fertility levels } \\
\hline$S_{1}$ Control & 18.31 & 37.74 & 56.06 & 32.81 \\
\hline $\mathbf{S}_{2} \mathbf{1 0 0 \%}$ NPK Chemical fertilizer & 39.75 & 50.31 & 90.07 & 44.15 \\
\hline $\mathbf{S}_{3} \mathbf{1 0 0 \%} \mathbf{N}(\mathbf{F Y M})$ & 31.79 & 46.95 & 78.74 & 40.39 \\
\hline $\mathrm{S}_{\mathbf{4}} \mathbf{5 0 \%} \mathrm{NPK}+\mathbf{5 0 \%} \mathrm{N}(\mathrm{FYM})$ & 36.62 & 48.59 & 85.22 & 43.00 \\
\hline $\mathrm{S}_{5} 75 \% \mathrm{NPK}+25 \% \mathrm{~N}(\mathrm{FYM})$ & 41.92 & 51.19 & 93.11 & 45.02 \\
\hline $\mathrm{S}_{6} 100 \% \mathrm{NPK}+25 \% \mathrm{~N}(\mathrm{FYM})$ & 43.52 & 52.63 & 96.15 & 45.26 \\
\hline SEm \pm & 0.32 & 0.31 & 0.58 & 0.28 \\
\hline$C D(P=0.05)$ & 0.93 & 0.89 & 1.67 & 0.81 \\
\hline
\end{tabular}


Fig.1 Effect of planting techniques and fertility levels on growth parameters of basmati rice

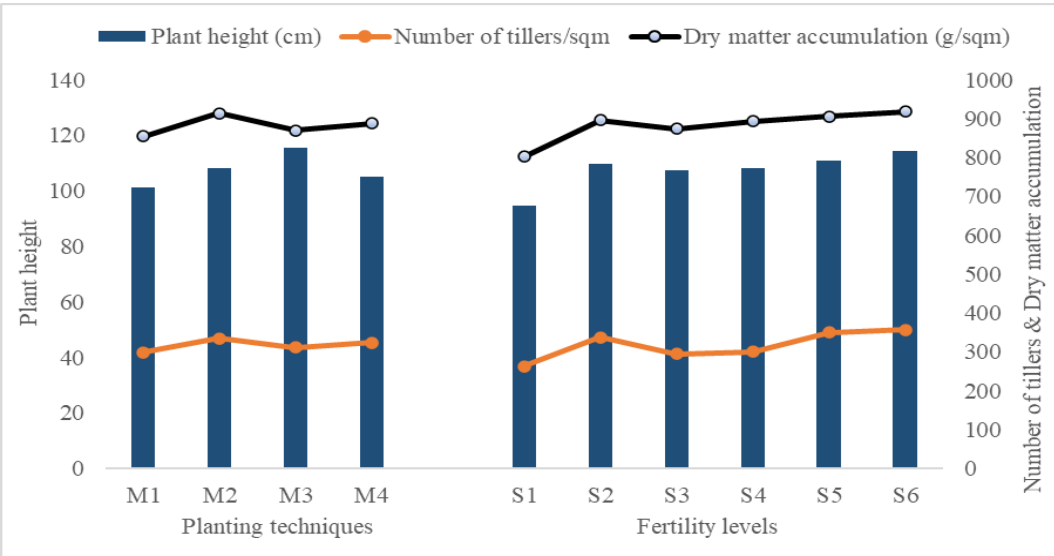

Fig.2 Effect of planting techniques and fertility levels on yield contributing characteristics of basmati rice

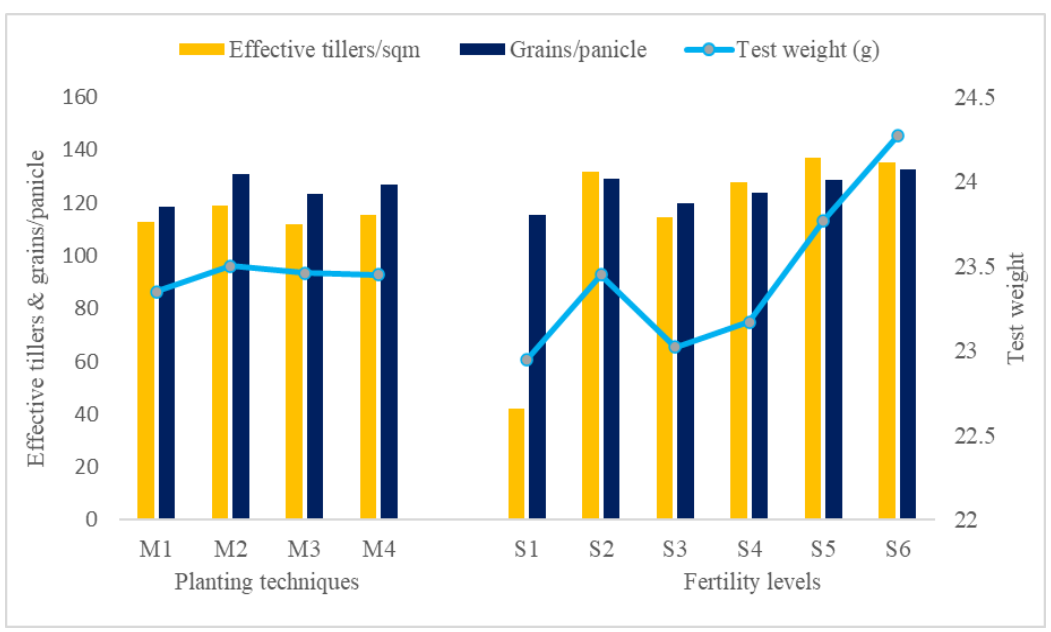

Fig.3 Effect of planting techniques and fertility levels on yield of basmati rice

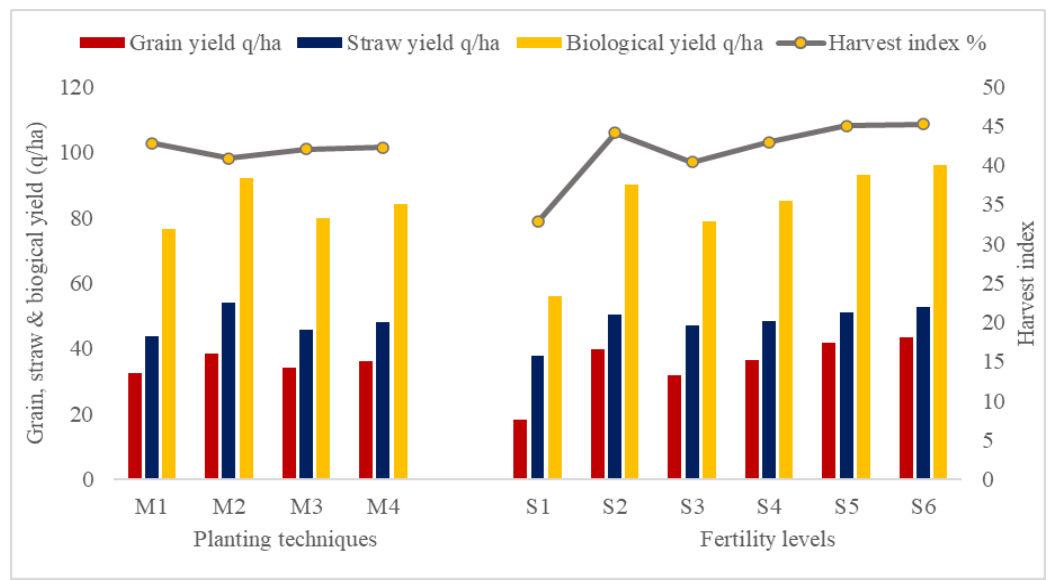


All yield attributes viz. effective tillers, grains per panicle and test weight shown significantly higher values in $\mathrm{M}_{2}$ (CT-TPR) while the lowest values of yield attributes were associated with in $M_{1}$ (RT-TPR). The higher values in yield attributes were mainly due to profuse tiller production \& more dry matter accumulation which is increase the translocation of photosynthates from source to sink. Yield attributes viz. effective tillers, grains per panicle and test weight are the resultant of vegetative development of the crop which determine yield were significantly influenced by fertility levels.

\section{Yield}

\section{Grain yield (q/ha)}

Planting techniques \& fertility levels shown significant variation in grain yield $(\mathrm{q} / \mathrm{ha})$ of rice (Table 3). The highest grain yield (38.37 q/ha) was recorded under the treatment $\mathrm{M}_{2}$ (CT-TPR). However, the lowest grain yield $(32.60 \mathrm{q} / \mathrm{ha})$ was noticed under M1 (RT-TPR). The highest grain yield was observed with application of $\mathrm{S}_{6}$ $(100 \% \mathrm{NPK}+25 \% \mathrm{~N}$ (FYM)) and the significantly lowest grain yield was associated with the control treatment.

\section{Straw Yield (q/ha)}

Planting techniques and fertility levels caused significant variation in straw yield $(\mathrm{q} / \mathrm{ha})$ of rice (Table 3). The maximum straw yield (53.91 $\mathrm{q} / \mathrm{ha}$ ) was recorded under the treatment $\mathrm{M}_{2}$ (CTTPR). However, the lowest straw yield (43.95 $\mathrm{q} / \mathrm{ha}$ ) was recorded under $\mathrm{M}_{1}$ (RT-TPR). The highest straw yield was observed with application of $\mathrm{S}_{6}(100 \% \mathrm{NPK}+25 \% \mathrm{~N}(\mathrm{FYM}))$ which was significantly higher rest of other treatments. However, the significantly lower straw yield was noticed under control treatment.

\section{Biological yield (q/ha)}

The highest biological yield $(92.28 \mathrm{q} / \mathrm{ha})$ was recorded under the treatment $\mathrm{M}_{2}$ (CT-TPR). The significantly lowest biological yield was recorded in $\mathrm{M}_{1}$ (RT- TPR) treatment. The maximum biological yield of $96.15 \mathrm{q} / \mathrm{ha}$ was recorded with the application of $\mathrm{S}_{6}(100 \%$ NPK $+25 \% \mathrm{~N}(\mathrm{FYM})$ ). However, the lowest biological yield $(56.05 \mathrm{q} / \mathrm{ha})$ was associated with control plots $\left(\mathrm{S}_{1}\right)$ (Fig. 3).

\section{Harvest index $(\%)$}

Harvest index refers to ratio of grain yield to biological yield did not shown any significant variation by planting techniques however the highest value (42.97\%) was recorded under $\mathrm{M}_{4}$ (UP-TPR). Lowest value of harvest index $(40.89 \%)$ was observed under the treatment $\mathrm{M}_{2}$ (CT-TPR). Fertility levels caused significant variance in harvest index of rice. The highest value of harvest index $(45.26 \%)$ was recorded with the application of $\mathrm{S}_{6}(100 \% \mathrm{NPK}+25 \%$ $\mathrm{N}(\mathrm{FYM})$ ) which is statistically at par with the treatment $\mathrm{S}_{5}$ [75\% RDF + 25\% $\mathrm{N}$ (FYM)] However the lowest harvest index value was associated with control treatment.

The integrated effects of fertilizer and farm yard manure were noted to be more beneficial than the use of chemical fertilizer alone. Additional increase in grain yield was registered due to the integrated effect of FYM with inorganic fertilizer. The increase in yield was further attributed to better translocation of photosynthetic products from source to sink due to higher uptake of NPK which are responsible for quick and easy translocation of photosynthetic products. The better vegetative growth coupled with high yield attributes resulted in higher grain and straw yield of rice. Similar results were also reported by Kumar et al., (2019). Higher level of fertilizers and FYM significantly influenced the growth development yield attributes and yield of rice reported by Gautam et al., (2012).

In conclusion among different planting techniques, conventional tillage-transplanted rice (CT-TPR) $\left(\mathrm{M}_{2}\right)$ recorded significantly maximum growth characters, yield attributes and yield over furrow irrigated raised beds (FIRB) $\left(\mathrm{M}_{3}\right)$ and reduced tillage-transplanted rice (RT-TPR) $\left(\mathrm{M}_{1}\right)$, which remained at par 
with unpuddled-transplanted rice (UP-TPR) $\left(\mathrm{M}_{4}\right)$ respectively. Among fertility levels treatments, the application of $100 \% \mathrm{NPK}+25 \%$ $\mathrm{N}$ (FYM) $\left(\mathrm{S}_{6}\right)$ found higher growth, yield attributes, and yield than rest of the other fertility treatments. Therefore, application of $\mathrm{M}_{2}$ (CT-TPR) along with $\mathrm{S}_{5}(75 \% \mathrm{NPK}+25 \% \mathrm{~N}$ (FYM)) found beneficial than other combinations of planting techniques and fertility levels.

\section{References}

Bhatt P, Kumar R and Chilwal, A. 2018. Effect of different tillage practices and precision nutrient management on energy use efficiency, economics and yield of wheat (Triticum aestivum L.) International Journal of Chemical Studies 6(5): 373376.

Directorate of Economics and Statistics. 201819. Department of Agriculture and cooperation, New Delhi, Ministry of agriculture Government of India.

Gautam O., Sharma G.D., Rana R and Lal B. 2012. Performance of hybrid rice INM in SRI under mid-hill condition of HP. Journal. Agriculture Sci. Carnbridg. 2012; 32(2):52-53.

Gill J.S. and Walia S.S. 2014. Influence of FYM, Brown Manuring and Nitrogen Levels on Direct Seeded and Transplanted Rice (Oryza sativa L.): A Review. Research Journal of Agriculture and Environmental Management. 3(9), pp. 417-426.

Jacobs A, Helfrich M, Hanisch S, Quendt U., Rauber R and Ludwig B. 2010. Effect of conventional and minimum tillage on physical and biochemical stabilization of soil organic matter. Biol Fertil Soils 46:671-680.

Kumar V, Naresh R.K., Tomar V.K., Kumar R, Vivek, Kumar R, Yadav, R.B., Mahajan, N.C., Singh A, Singh, S.P., Chandra S and Yadav O.S. 2019. Growth, Yield and Water Productivity of Scented Rice (Oryza sativa L.) as Influenced by Planting Techniques and Integrated Nutrient Management Practice. International Journal of Current Microbiology and Applied Sciences 8(06): 2319-7706.

Mahmud A.K., Shamsuddoha A.T.M. and Haque M.N. 2016. Effect of Organic and Inorganic Fertilizer on the Growth and Yield of Rice (Oryza sativa L.) Nature and Science 2016; 14(2).

Naresh, R.K., Singh, S.P. and Pankaj Chauhan. 2012. Influence of conservation agriculture, permanent raised bed planting and residue management on soil quality and productivity in maize-wheat system in western Uttar Pradesh. Int. J. LifeSc. Bt \& Pharm. 1(4): 2250-3137.

Singh, N.P., Singh, M.K., Tyagi, S. and Singh, S.S. 2018. Effect of Integrated Nutrient Management on Growth and Yield of Rice (Oryza sativa L.). International Journal of Current Microbiology and Applied Sciences, (7)3671-3681.

Tomar, R., Singh, N.B., Singh, V. and Kumar, D. 2018. Effect of planting methods and integrated nutrient management on growth parameters, yield and economics of rice, Journal of Pharmacognosy and Phytochemistry, 7(2): 520-527.

\section{How to cite this article:}

Naveen Kumar, G., P. K. Singh, R. K. Naresh, M. Sharath Chandra and Akash Kumar. 2021. Effect of Planting Techniques with Organic and Inorganic Nutrient Management on Growth, Yield Attributes and Productivity of Rice (Oryza sativa L.) under Rice-Wheat Cropping System. Int.J.Curr.Microbiol.App.Sci. 10(01): 328-336. doi: https://doi.org/10.20546/ijcmas.2021.1001.041 